\title{
Three Coleopterous Tree Borers Newly Recorded in Egypt
}

\author{
Hedaya H. Karam, Hanan M. Ramadan, Abdel-Aziz M. El-Minshawy and \\ Rehab R. E. Mohammad \\ Department of Applied Entomology and Zoology, Faculty of Agriculture, Alexandria University
}

\begin{abstract}
During a taxonomic study on tree borers in Egypt, three beetles of them were recorded for the first time in Egypt. They were Bostrychoplites sp. and Heterobostrychus equalis (Waterhouse, 1884) belonging to family Bostrichidae and Acanthoscelides macrophthalmus (Schaeffer, 1907) belonging to family Bruchidae. In this study illustrated description of these species were given with the collecting date, location and host plant.
\end{abstract}

Key words: Coleoptera, Tree borers, New in Egypt.

\section{INTRODUCTION}

Taxonomic studies, ususally aim to collect a definite group of insects and identify their species in hope of finding a new species or at least a newly recorded ones in a geographical region. The Egyptian fauna of insects increased continously due to the devolped survey and taxonomic studies. In this work three coleopterous tree boreres were recorded for the first time in Egypt. Two of them were belonging to family Bostrichidae and one from family Bruchidae.

Several authors allover the world gave description, taxonomical keys of subfamilies, genera and species of family Bostrichidae (e.g. Chujo, 1936- 1940; Fisher, 1950; Badawy and Naguib, 1961; Moussa, 1977; Carrillo et al., 2001; Ivie, 2002; Filho et al., 2006; Liu et al., 2006; Woodruff and Thomas 2006; De La Puebla et al. 2007; Beiriger 2010; Liu 2010; Azmi et al. 2011; Liu and Schnitzer, 2011; Bonsignore, 2012; Lopez-Perez, 2012; Luna Murillo and Obregon, (2013; Kollar, 2014; Hava and Chaboo, 2015; Nardi and Mifsud, 2015; Park et al., 2015; Liu et al., 2016 and Wylie and Brenton, 2016).

Family Bruchidae (seed beetles) may infest the pods of ornamental or wood trees, hence they can considered as tree borers. In Egypt, Shomar (1963) surveyed bruchid beetles from leguminous plants, flower of Umbelliferae and Convolvulacaea from allover Egypt. Also, she examined specimens of different Entomological collections in Egypt, namely in the Ministry of Agriculture, Cario and Ain Shames Universities, Entomological Society of Egypt and also, Alfieri's private collection. She recorded and gave an illustrated description to fifty one species of eight genera belong to family Bruchidae based on the characteristic denticulation of posterior femora, tibia and thorax. Also, she gave keys for identification of species and the accurate description of each species. In the present study the recorded species Acanthoscelides macrophthalmus (Schaeffer) was not among these fifty one species, therefore it is recorded as new to the Egyptian fauna. Several literature on this genus were puplished in different regions of the world (e.g. Bousquet, 1990; Johnson, 1990; Kingsolver, 2004; Wu et al., 2007; Vassiliou and Papadoulis, 2008; Nápoles and Kingsolver, 2009; Thakur, 2012a \&b; Thakur and Kalpna, 2015).

The aim of the present study is to high light the discovery of these newly recorded species and give description of them.

\section{MATERIALS AND METHODS}

Samples of infested pods by bruchid beetle were collected, from Leucaena leucocephala trees in the garden of Faculty of Agriculture, Alexandria University $\left(31^{\circ} 12^{\prime} 18.62^{\prime \prime} \mathrm{N}, 29^{\circ} 55^{\prime} 8.86^{\prime \prime}\right.$ E) and the Plant Protection Institute Experimental Research Station in Al-Sabahia ( $31^{\circ} 21^{\prime} 29.17^{\prime \prime} \mathrm{N}, 29^{\circ} 98^{\prime}$ 78.06” E). Heterobostrychus aequalis samples were collected by light trap in the Faculty of Agriculture Alexandria University and the samples of Bostrychoplites sp. was collected from mango trees from El-Nubaria district $\left(\begin{array}{lllll}30^{\circ} & 8181 & 34,29^{\circ} & 98 & 74\end{array}\right.$ 13).

Samples of infested branches or pods were kept in ventilated containers until the adult emerged. The containers were labeled by the information of date, location of collecting and host plant.

The subfamily, genus of the bostrichid beetles were identified by using the key of Ivie, (2002) and all species were identified by the key of Liu et al., (2006). The terminology used in this study for Family Bruchidae.according to Shomar, (1963); Kingslover, (2004) and Napoles et. al., (2009)

The morphological characters of each specimen, were photographed by a digital camera, then drew under stereoscopic microscope. All the illustrated diagnostic characters were measured by using the micrometric lens.

To make sure that the species under study were not recorded before in Egypt, their names were revised the comprehensive list of Coleoptera of Egypt (Alfieri, 1976) which comprises a table of 2974 species belonging to 63 families. In addition, some 
authorized entomological collections were visited for confirming the identification of the species such as the collection of Ministry of Agriculture and the Plant Protection Institute, Dokki, Giza.

The world distribution and host plants for each species was based on Global Biodiversity Information Facility (GBIF: http://www.gbif.org).

\section{RESULTS AND DISCUSSION}

\section{A- Family: Bostrichidae:}

Bostrichidae has medium-sized beetles, widely distributed family having 90 genera and 600 species.
It divided into subfamilies, Bostrichinae, Dinodrinae, Lyctinae, Dysidinae, Psoinae, Endecatominae and Polycaoninae (Ivie, 2002). This family is composing economically important beetles which can cause extensive damage to dry and dead wood, seasoned sapwood timber, bamboo and to wooden bamboo artifacts through the boring behavior of both adults and larvae (Liu et. al., 2006). It referred to as powder post beetles because of their ability to reduce wood to thin external shell covering the frass produced by the boring activities.

\section{Key to the world subfamilies of Bostrichidae (after Ivie, 2002)}

1 Pronotum with explanate lateral margins with row of projecting straight or recurved setae; elytra with unisteose microtubercles arranged in an irregular, reticulate pattern, cuticle smooth between Endecatominae

-Pronotum with or without distinct lateral margins, but margins not explanate; elytra smooth, tuberculate, punctuate or rugose, not as above .............. 2

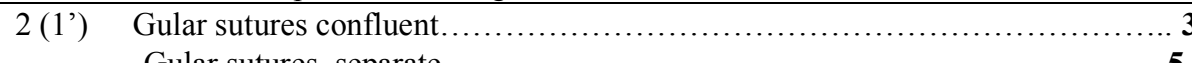

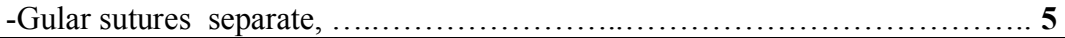

3(2) Head easily visible from above, prosternal process long, reaching mesosternum and slightly expanded at apex; antenna 9-11 (usually 11) segments

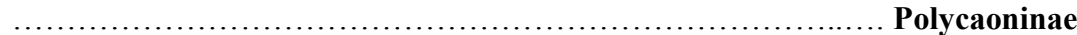

-Head more or less covered by pronotum, prosternal process short, acute, not expanding between procoxae; antenna 8-10 (usually 10) segments ............4

4(3') Protibia with 1 apical spine; prothorax in dorsal view evenly rounded in front, first tarsomere sub equal to second. Dinoderinae

-Protibia with 2 apical spines; prothorax in dorsal view flattened or excavate in front, first tarsomere very much shorter than second. Bostrichinae

5(2') Hind trochanter attached squarely to femur; first tarsomere almost always longer than

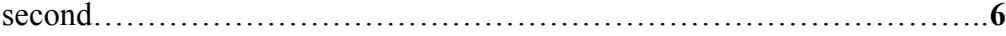

-Hind trochanter obliquely attached to femur; first tarsomere shorter than second, or tarsi 4

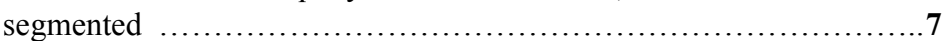

6(5) Hind coxae usually excavate to receive hind femur, with at least a flat, posterior face and carina along ventro-posterior margin, if not, antennal insertions approximate and antennae without pectinate 3 segmented club; worldwide (Treated as Anobiidae) .......................................... Anobiinae

-Hind coxae conical at trochanter insertion, not excavate to receive hind femur; antennal 11 segmented with a 3 segmented pectinate club each ramus longer than antenna; New Zealand

Euderiinae

$7\left(5^{\circ}\right)$ Pronotum with complete lateral margins; antennae 11 segmented, usually with a 2 rarely 3 segmented club; procoxae widely separated, procoxal cavities open or closed externally (Treated as Lyctidae). Lyctinae -Pronotum without lateral margins or with only basal portion margined; antennae with 11 or less segmented, club with 3 or 4 segments; procoxal cavities open

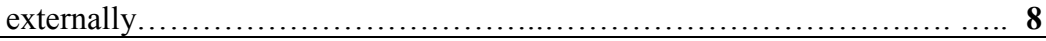

8(7') First ventrite with a postcoxal carina complete across its width, connected to wide intercoxal process............................................ Dysidinae

-First visible sternite of abdomen (or second if first visible is II, narrowly visible at lateral edges in some genera)usually without a postcoxal carina, with intercoxal process lamiform or absent. 
Subfamily: Bostrichinae

Tribe: Bostrichini

1-Bostrychoplites sp.

Diagnostic characters of the male:

Body elongate; length $13 \mathrm{~mm}$, width $3.5 \mathrm{~mm}$; brownish black in colour, palpi and antennae reddish brown; dorsal surface of body glabrous. (Fig. 1A)

Head: combletly covered by pronotum (Fig. 1 A $\& C)$, constricted behind eyes, with longitudinal punctation on the middle of vertex and transverse depression between vertex and front; labrum and labium provided with long reddish brown hairs at apex. Eyes: large,strongly protruding, coarsely faceted, gena with two dents below eyes (Fig. $1 \mathrm{C}$ ). Antenna: (Fig. 1 D) short, arise immedietely next to eyes, 10 segmented, first and second segments robust elongate, second shorter than first, third to seventh segments short, transverse, 3 terminal segments strongly clubbed, antennal club segments 1 and 2, tirangulare, last segment oval shaped.

Pronotum (Fig.1 E) quadrate, strongly convex, strongly deflexed anteriorly, arcuately emarginate in front; sides broadly rounded, with a large, broad, horns at apical angles in male; each horn with upcurved apex and 3 large teeth followed by 2 smaller ones; posterior angles broadly rounded; surface sparsely, irregularly punctate at sides on basal half, densely, coarsely punctate at middle on basal half, densely, irregularly dentate on apical declivity, the teeth broad, semierect, and rasplike, with three larger teeth on each side toward lateral margin. Elytra at base subequal in width to pronotum, truncate at base; broadly rounded at apices; margins sinuate; surface coarsely, densely, punctate, the punctures arranged in rows on disk. Legs: (Fig. 1 B) $1^{\text {st }}$ and $2^{\text {nd }}$ coxae globose, contiguous, third coxa transverse and narrowly separate; all tibiae ended with 1 curved spur, outer margine armed with small teeth; tarsai 5 segments, $1^{\text {st }}$ one very short, $2^{\text {nd }}$ segment almost as long as the last one.

Abdomen: (Fig. 1 B) with 5 visible sternite, rather densely clothed with short, recumbent, yellowish hairs, the hairs longer at apex of last sternite.

Examined materials: 1speciemen (male) emergened from mango branches in October 2016.

Remaks: This African species is represented by 15 species allover the world ( Ivie, 2002). In Egypt two species were recorded (i.e. B. cornutus Olivier and $B$. zickeli Marseul). The former species was recorded according to Winkler's Catalogue, while the other one, B. zickeli was collected from Cairo, Faiyum and Minya (Alfieri, 1976). also, from Quena, Hammad and Aly (1985). By comparing the characters of our specimen with the photos of $B$. zickeli in the net different cites, we found some differences in the shape of pronotal horns. We could not identify the species because of the lacking of a key to species rank and more specimens are needed. The genus name was kindly confirmid by Dr LanYu Liu, Department of Entomology, Chung Hasing University Taichung, Taiwan.

2 -Heterobostrychus aequalis (Waterhouse, 1884) Diagnostic characters:

Body elongate, cylindrical, dark brown, moderately glossy, glabrous. Length range from 9 to $13 \mathrm{~mm}, 2$ to $3.5 \mathrm{~mm}$ wide. Head: not visible from above (Fig. 2C), transversely constricted behind eyes. Eyes rounded, protruding. Antenna: (Fig, 2 D), 10 segments, with 3 terminal segments forming a loose asymmetrical club, each segment with two indistinct nearly circular sensory areas, first and second segments of club sub equal in length, sub triangular, apical segment oblong or elongate.

Pronotum: (Figs. 2 A \& C) strongly convex, quadrate, anteriorly deflexed, transversely depressed behind anterior margin, arcuately marginated in front; anterior half with four broad, tooth like marginal tubercles, emargination between anterior teeth of pronotum broad extending about three quarters of distance between eyes; posterior angles with one tubercle, slightly lobed. Elytra: (Figs 2A \& C), abruptly descend to abdomen, densely, deeply punctate, punctures arranged in fairly distinct rows, elytral apical declivity excavated and variable between the sexes, males possess two stout tubercles, the outer forming an elongate costa, the inner forming a strong, pointed tooth directed upwardly (hook-like projections), not seen in female Examined material: 2 specimens $1 \mathrm{male}$ and 1 female, collected by light trap at the summer of 2012

Hosts: This species has been recorded from 35 species of trees including the following genera: Adina, Albizzia, Anisoptera, Anogeissus, Bambusa, Bombax, Boswellia, Canarium, Cassia, Cedrela, Dalbergia, Dendrocalamus, Dipterocarpus, Endospermum, Garuga, Koompassia, Kydia, Lannea, Leucaena, Mangifera, Morus, Parashorea, Parishia, Poinciana, Pterocarpus, Quercus, Shorea, Sterculia, Tectona, and Terminalia. Only oak and Philippine mahoganies have been found infested in Florida

http://entnemdep.ufl.edu/creatures/trees/oriental_wo od borer.htm

Distribution: $H$. aequalis distribute dominantly in tropical and sub-tropical areas, and widely distributed in Asia, particularly Southeast Asia to Oceania, some parts of Africa, Central America and Caribbean region (Azmi et al. 2011).

Remarks: According to the revision of the Egyptian collections and the available literature and theses, we found that this species is not exist in the Egyptian fauna so it is considered to be new record in Egypt. 

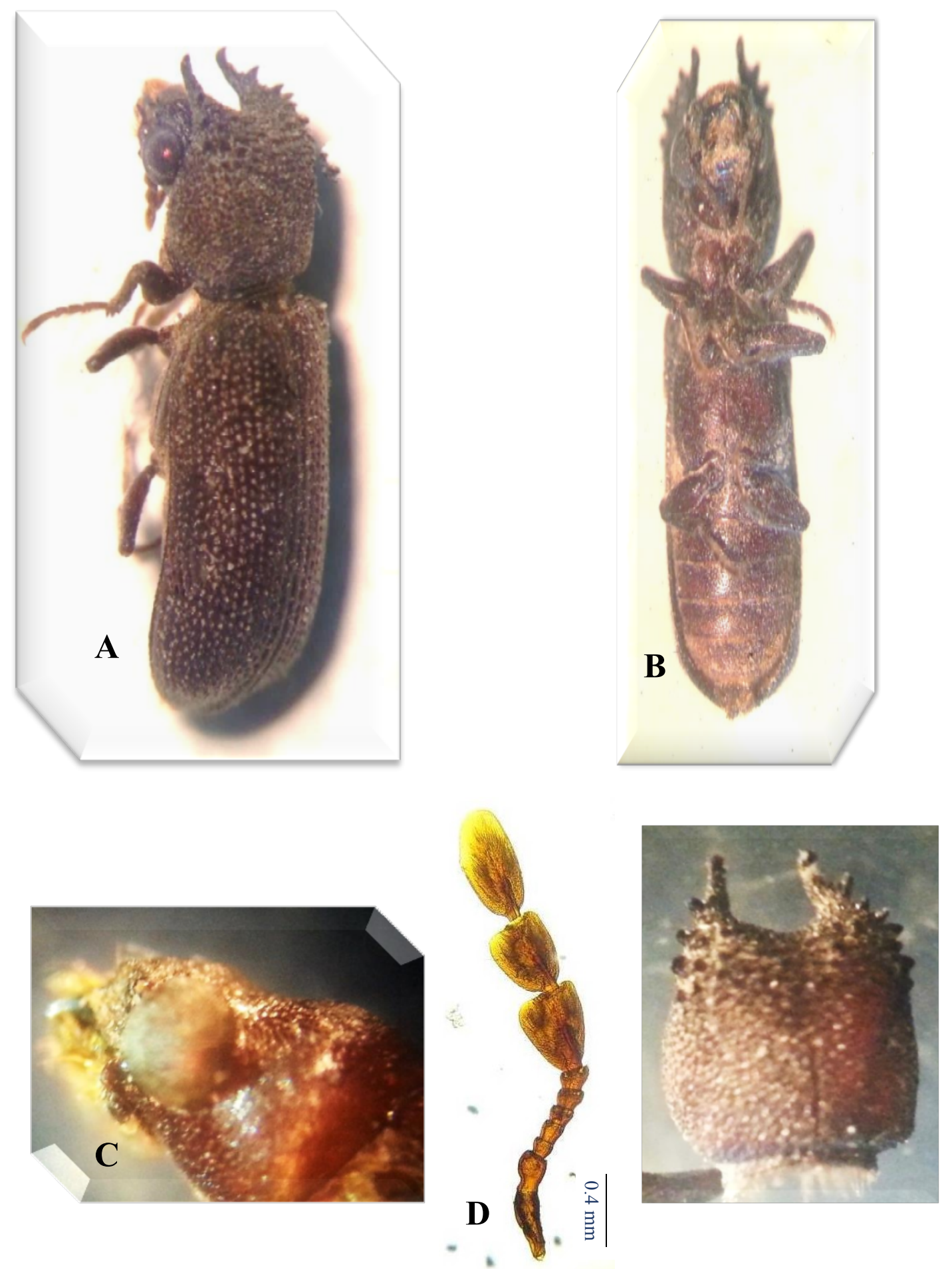

Figure 1: Bostrychoplites sp. - male A: lateral view, B: ventral view, C: magnification of head showing the dents below eyes (arrow), D: Antenna, E: pronotum. 

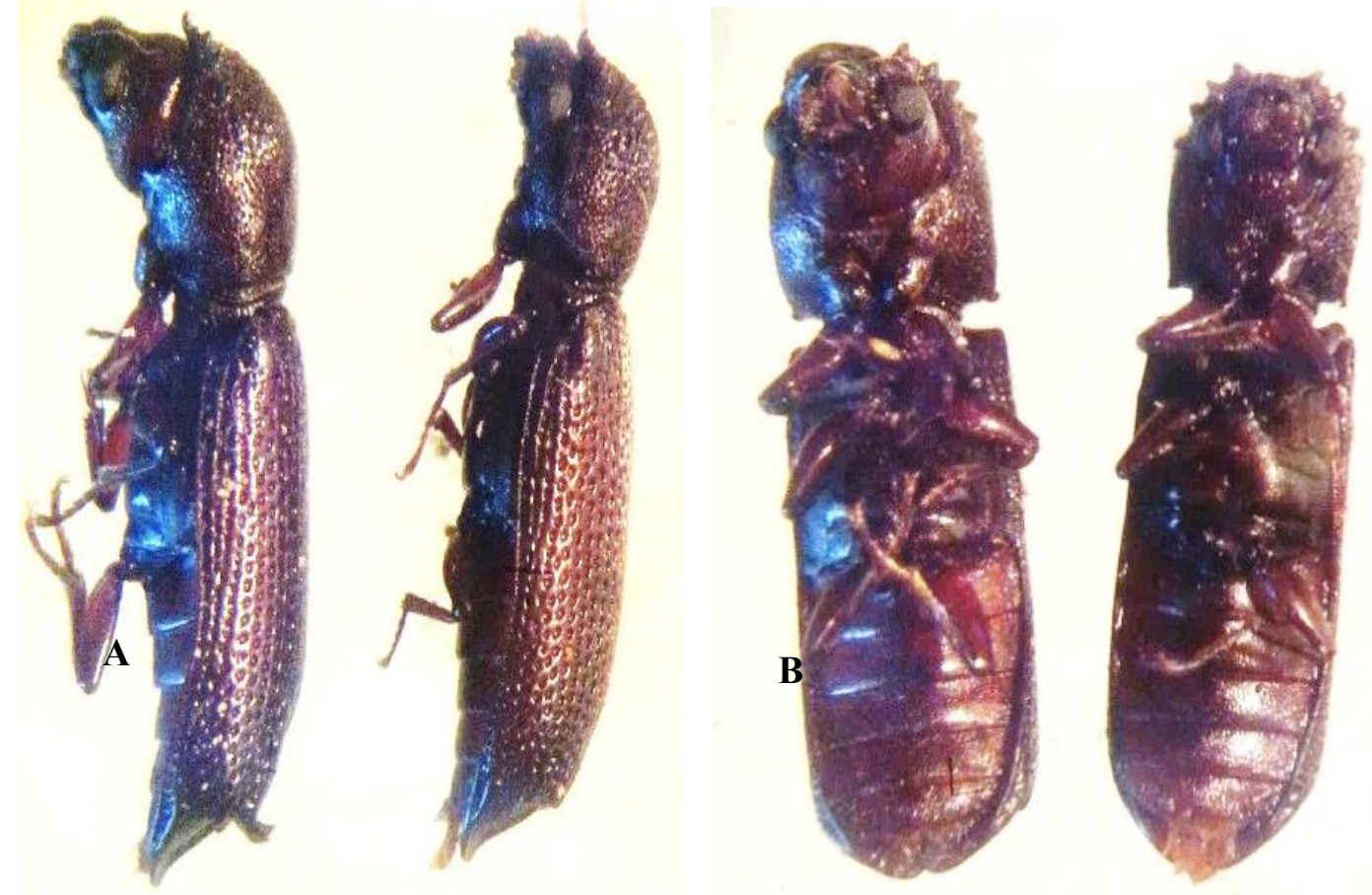

C
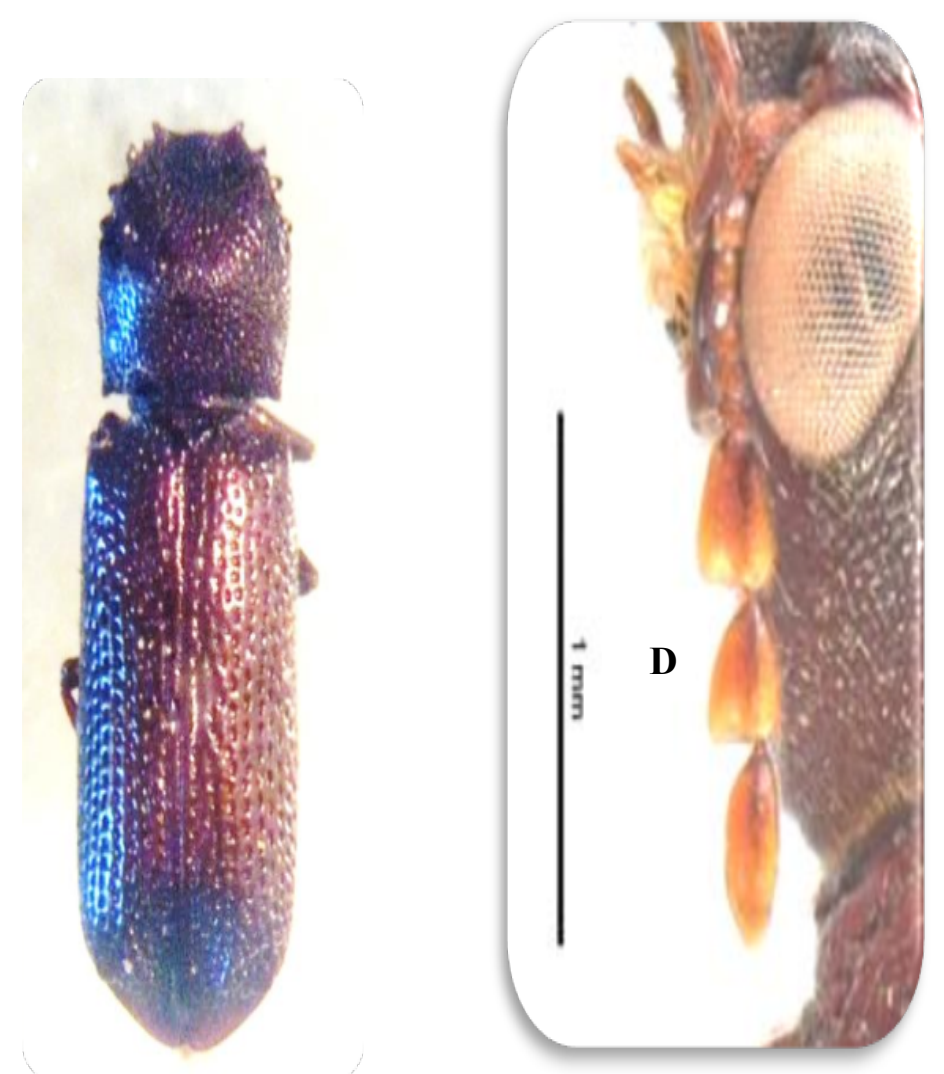

Figure 2: Heterobostrychus aequalis - A: lateral view (left male, right female), B: ventral view (left male, right female), C: female dorsal view, D: Antenna(c.f http://www.padil.gov.au) 


\section{B- Family Bruchidae (seed beetles)}

Bruchids are found in all parts of the world except around the poles and over most of the Pacific area, commonly known as seed beetles. This is a moderate-sized family represented by 1700 described species and about 60 genera grouped in the 6 subfamilies: Amblycerinae, Bruchinae, Eubaptinae, Kytorhininae, Pachymerinae, and Rhaebinae (Johnson, 1990). About $80 \%$ of bruchid species are in the Bruchinae, $10 \%$ in the Amblycerinae, 9\% in the Pachymerinae, with the other $1 \%$ in the other three subfamilies. They characterized by: Body ovoid, compact, short, stout mostly less than $5 \mathrm{~mm}$ in length. Head deflexed, covering prosternum and procoxae, neck long, frontoclypeal region produced into broad, rather flat muzzle, hypognathous or opisthognathous; ocelli absent, eyes large, shallowly to deeply emarginat. Antennae usually compressed, gradually thickened from $5^{\text {th }}$ segments to apex, 11-segmented with insertion adjacent to eye, serrate, or pectinate, not abruptly clubbed, rarely filiform, short not reaching beyond shoulders of elytra, mandibular apex acute, not dentate; gular sutures short. Prothorax with lateral edges usually incomplete. Elytra short leaving tip of abdomen exposed, elytral striae always present, usually 10 in number. Body clothed with recumbent hairs or scales, and usually dull grayish, black or brownish color, rarely metallic with patterns of spots.

Symptoms of infestation by bruchid beetles:

The larvae live and eat inside the seeds. In the spring and summer many pods are found with holes, the seeds inside are also with circular neat holes leading into the cavity were the insect develop (Fig. $3)$.

Sub family Bruchinae

Tribe Achanthoscelidini

Acanthoscelides macrophthalmus (Schaeffer, 1907)

Diagnostic characters:

Body length 2.5-3 mm, width $1.8-2.0 \mathrm{~mm}$, reddish brown in colour, with dark marginal shading on elytra, basal and apical part of elytra dark brown, as well as the humeral lateral half, the latter mottled with small light spots. Vestiture of fine white setae, except 3 bare spots on pronotum at the angles of a triangular shape, pattern usually more pronounced in females (Fig. 4).

Head: (Fig. 5 A) hypognathous, vertex and frons usually with unisetose punctures. Eyes: protruding, rough faceted, often sexually dimorphic with eyes larger in male than in female, partly divided by setaceous ocular sinus. Antenna: (Fig. 5 B) insertion at anterior margin of eye, with 11 antennomers, 1-3 slender, subserrate from $4^{\text {th }}$ segment except $11^{\text {th }}$ segment elliptical, with an apical basiconic senselum, often sexually dimorphic with male antenna longer or broader.

Pronotum: (Fig. 5D) conical, short, convex, posteriorly sinuate with acute angles, puncture coarse and close to each other. Scutellum small rounded behind. Elytra (Fig. $6 \mathrm{C}$ ) about twice as long as broad, with 10 steriae consist of longitudinal punctures moderately impress, each puncture with a long seta, steria 4,5 meet together at apex, Legs: procoxae oblong, narrowly separate, their cavities open behind (Fig. 5 E), hind coxa hemispherical in shape, hind femur thickened (Figs. 4 B, 5 F), armed at inner margin with 3 subapical acuminate spines, $1^{\text {st }}$ stout, 2,3 closely small teeth, hind tibia moderately arcuate, dilated toward apex, ventral and dorsomesal carina always present, apex with acute spine (mucro) on ventral margin, tarsus with 4 tarsomers, $1^{\text {st }}$ one the longest, $2^{\text {nd }}$ almost as long as $4^{\text {th }}, 3^{\text {rd }}$ segment small .

Abdomen: with 5 visible sternite, pygidium ranging from evenly rounded to strongly convex, apical margin of last sternum of male slightly emarginated to receive apex of pygidium (Fig. 5H), apical margin of last sternum of female usually without emargination (Fig.5 G), male pygidium usually strongly inflexed at apex, female pygidium usually vertical at apex

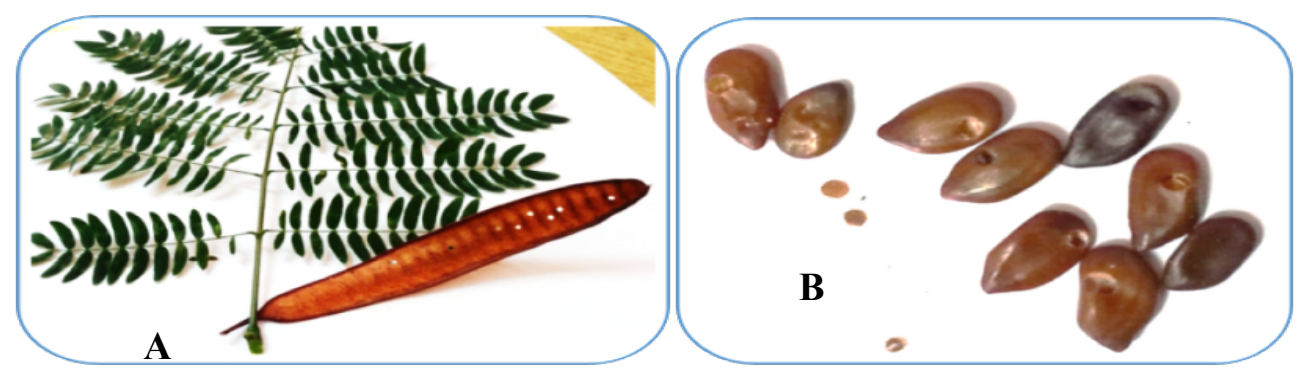

Figure 3: symptoms of infestation by Acanthoscelides macrophthalmus on Leucaena tree A: emergence holes in pods, B: emergence holes in seeds 

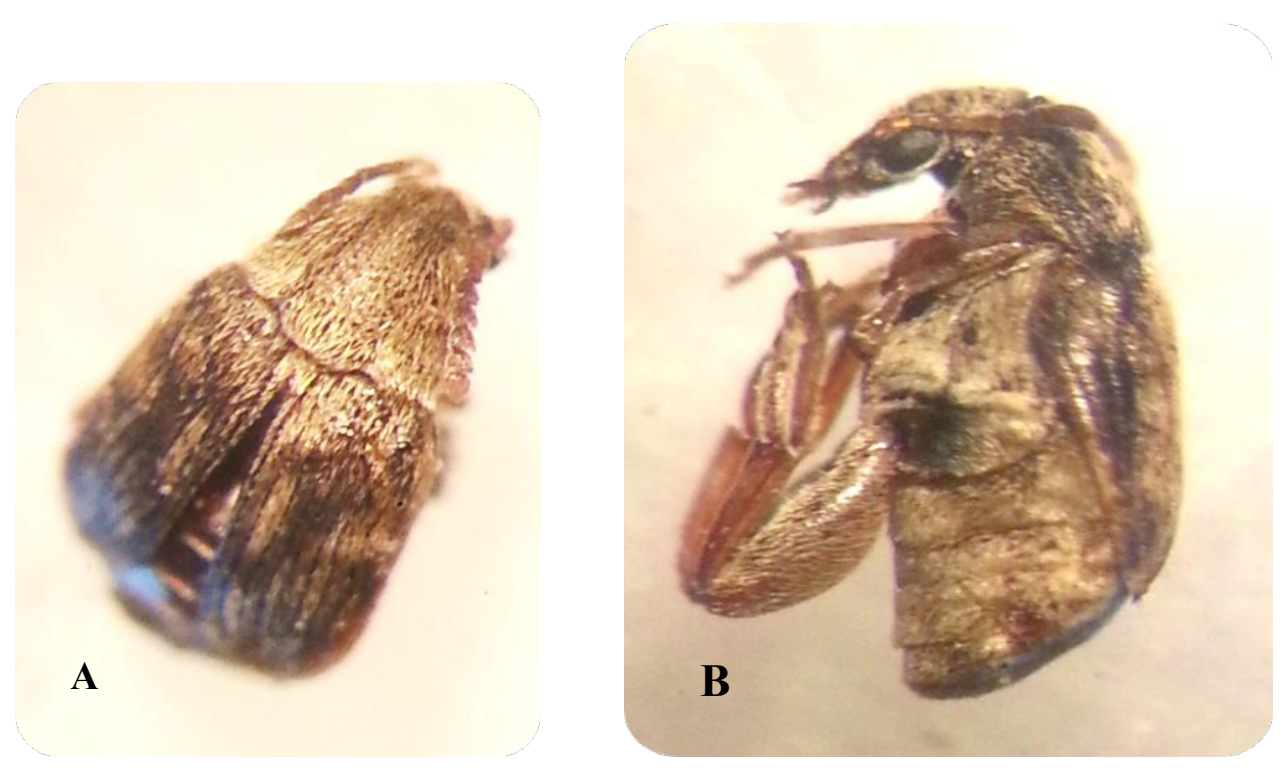

Figure (4) Acanthoscelides macrophthalmus A: dorsal view B: lateral view
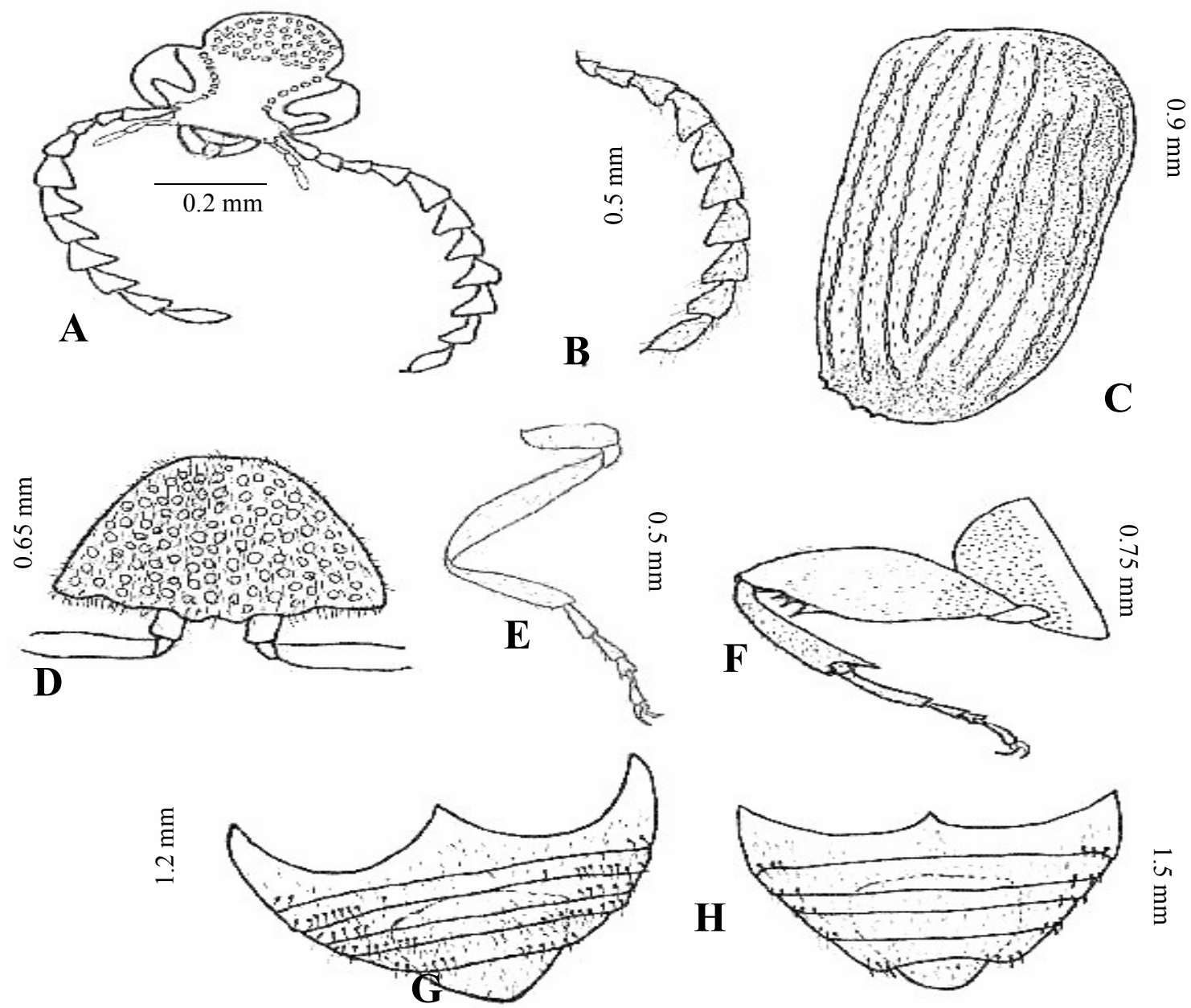

Figure 5: Diagram of Acanthoscelides macrophthalmus A: head capsule, B: antennae C: elytra D: pronotum $\mathrm{E}$ : fore leg $\mathrm{F}$ : hind leg $\mathrm{G}$ : female abdomen $\mathrm{H}$ : male abdomen 
Examined material: 5 specimens emerged from Leucaena pods in May and August 2016, 2 males and 3 females.

Hosts: leadtree spp. - Leucaena leucocephala, L. pulverulenta and L. retusa (Fabaceae)

Distribution: America, North America, Oceania, India, Taiwan and Cyprus.

Remarks: According to the revision of the collection of Ministry of Agriculture, the Plant Protection Institute, Dokki, Giza and the checklist of Alfieri (1976), this specie is not exist in the Egyptian fauna. Also the extensive work of Shomar (1963) did not record it; therefore it could be first record in Egypt.

\section{REFERENCES}

Alfieri, A. (1976). The Coleoptera of Egypt. Mem. Soc. Ent. Egypt. Bull. Soc. Ent. Egypt 5223 pp.

Azmi, M.S.; Abood, Faizah and Razi N. A. (2011). World distribution of Heterobostrychus aequalis Waterhouse (Coleoptera: Bostrychidae). Journal of Entomology 8(6): 49 $-511$.

Badawy, A. and Naguib, Fawzia,. (1961). External morphology of the adult Sinoxylon sudanicum Lense (Coleoptera: Bostrychidae). Bull. Soc. Ent. Egypte : 233 - 243.

Beiriger, R. (2010). Heterobostrychus hamatipennis Lesne (Coleoptera: Bostrichidae) new to Florida. Insecta Mundi 0138: 1-5.

Bonsignore, C. P. (2012). Apate monachus (Fabricius, 1775), a Bostrichid Pest of Pomegranate and Carob Trees in Nurseries Short Communication. Plant Protect. Sci. 48 (2): 94-97.

Bousquet, Y. (1990). Beetles associated with stored products in Canada. An identification guide.Ministery of Supply and Services, Canada 1990. pp 214.

Carrillo, E. F.; Jose L. F. C. and Jose, I. L. C. (2001). Los Bostrichidae de la provincia de Ciudad Real (Coleoptera). Bol. S. E. A. (29): $41-44$.

Chujo, M. (1936 -1940). Insects of Micronesia (Coleoptera: Bostrichidae). This represents, in part, Results of Professor T. Esaki's Micronesian Expeditions (1936-1940), No. 93: $85-104$.

De La Puebla, P. B.; Lopez-Colon, J. I. and Baena, M. (2007). Los Bostrichidae Latreille, 1802 de la fauna ibero-balear (Coleoptera). Heteropterus Rev. Entomol. 27(2): $147-227$.

Filho, O. P.; Teixeira, É. P.; Bezerra, M.L.M.; Dorva, A.and Filho, E. B.( 2006). First record of Sinoxylon conigerum Gerstäcker (Coleoptera: Bostrichidae) in Brazil. Neotrop. Entomol. vol.35 no.5
Fisher, W. S. (1950). A revision of the north American species of beetles belonging to the family Bostrichidae.United States Depatment of Agriculture Miscellaneous publication No, 698. $157 \mathrm{pp}$.

Hammad, N. F. and Aly, M. Z. J. (1985). Seasonal fluctuations of certain species of nocturnal Coleoptera as indicated by a light trap at Qena. Quatar Univ. Sci Bull. 5: 287 - 304.

Hava, J. and Chaboo, Caroline S. (2015). Beetles (Coleoptera) of Peru: A survey of families. Nosodendridae Erichson1846 (Derodontoidea, Dermestidae Laterielle, 1804, Bostrichidae Laterielle, 1802, Bostrichoidea). J. Kansas Entom.Soc. 88 (3) 404-407.

Ivie, M. A. (2002). Bostrichidae. In: Arnett, Jr.R. H.; Thomas, M. C.; Skelley, P.E. and Frank, J. H. (Eds.). American Beetles vol.2 (pp. 233244). Boca Raton, Fla: CRC Press.

Johnson, C. D. (1990). Systematics of the seed beetle genus Acanthoscelides (Bruchidae) of Northern South America. Transactions of the American Entomological Society. 116(2): $29-$ 618

Kingsolver, J. M. (2004). Hand book of the Bruchidae of the United states and Canada (Insecta, Coleoptera). USAD Technical bulletin vol I \& II, N. 1912: pp. 319.

Kollar, J. (2014). Scobicia chevrieri (Villa Villa 1835), a new species of the Bostrichidae family for the Slovak Republic - Short Communication. Journal of forest Science 60(8): $349-350$.

Liu, L. (2010). New records of Bostrichidae (Insecta: Coleoptera, Bostrichidae, Bostrichinae, Lyctinae, Polycaoninae, Dinoderinae, Apatinae). Mitt. Münch. Ent. Ges. 100: $103-117$

Liu, L.; Beaver, R. A. and Yang, J. T. (2006). The Bostrichidae (Coleoptera) of Taiwan: a key to species, new records, and a lectotype designation for Sinoxylon mangifera Chujo. Zootaxa 1307: 1 - 33 .

Liu, L.; Ghahari, H. and Beaver, R. A. (2016). An annotated synopsis of the powder post beetles of Iran (Coleoptera: Bostrichoidea: Bostrichidae). J. insect biodiversity 4 (14):1-22

Liu, L. Y. and Schnitzer, K. (2011). Phylogenetic analysis of the family Bostrichidae auct. At superageneric levels (Coleoptera: Bostrichidae). Mtu. Monch. Ent. Gus. 101: 99 - 132.

Lopez-Perez, J. J. (2012). Los Bostrichidae Laterelle, 1802 (Coleoptera, Bostrichoidea) de la provincia de Huelva (S. O. de Andalucia, Espana). Revista gaditana de Entomolgia, Vol III (1-2): $23-28$. 
Luna Murillo, A. and Obregon, R. (2013). Nuevas aportaciones a la faune de Bostrichidae (Coleoptera) de la provicia de Cordoba (Andalucia, Espana). Boletin de la SAENo 21: $46-57$.

Moussa, M. E. (1977). Studies on wood-boring insects. Ph.D. thesis, Faculty of Agriculture, University of Alexandria: $351 \mathrm{pp}$.

Nápoles, J. R. and Kingsolver, J. M. (2009). A new species of Acanthoscelides Schilsky (Coleoptera: Bruchidae) from Mexico with some biological notes. Neotrop. entomol. vol.38 (4) http://dx.doi.org/10.1590/S1519566X2009000400009.

Nardi, G. and Mifsud, D. (2015). The Bostrichidae of the Maltese Islands (Coleoptera) ZooKeys 481: 69-108: doi: 10.3897/zookeys.481.8294.

Park, S.; Lee, S. and Hong, K.(2015) Review of the family Bostrichidae (Coleoptera) of Korea. Journal of Asia-Pacific Biodiversity 8: 298-304

Shomar, Naggat, F. H. (1963). A monographic revision of the Bruchidae of Egypt (U.A.R.). Bull. Soc. Ent. Egypt, XLVII: $141-196$.

Thakur, D. R. (2012a).Taxonomy and distribution of Acanthoscelides macrophthalmus (Schaeffer) (Coleoptera: Bruchidae) from India.Journal of Insect Science (Ludhiana). Vol.25 (1): 64-69.

Thakur, D, R. (2012b). Taxonomy, Distribution and Pest Status of Indian Biotypes of Acanthoscelides obtectus (Coleoptera: Chrysomelidae: Bruchinae) A New Record. Pakistan J. Zool., vol. 44(1): 189-195.
Thakur, D. R. and Kalpna (2015). SEM description and life history traits of Indian Biotype of Acanthoscelides macrophthalmus (Schaeffer) (Coleoptera: Bruchidae). International Journal of Zoological Research 11(1): 19 - 28 .

Vassiliou, V. A. and Papadoulis, G. (2008). First record of Acanthoscelides macrophthalmus (Schaeffer) (Coleoptera: Bruchidae) in Cyprus. Entomologia Hellenica 17 (2007-2008): 5255.(short communication).

Woodruff, R. E. and Thomas, R. F. (2006). An oriental wood borere, Heterobostrychus aequalis (Waterhouse) (Insecta: Coleoptera: Bostrichidae). University of Florida, IFAS Extension website at http://edis.ifas.ufl.edu

Wu, H. S.; Wu, W. J.; Wang, C. P.; Chen, S. W. (2007). A new record of bruchid beetle from Taiwan (Acanthoscelides macrophthalmus) (Coleoptera: Bruchidae). Plant Protection Bulletin (Taipei) Vol. 49 (1): 75-80.

Wylie, F. R. and Brenton, C. P. (2016). Lesser auger beetle Heterobostrychus aequalis (Coleoptera: Bostrichidae) in Australia: absent or elusive?. Austral Entomology 55: 330 - 333.

\section{Internet sites}

http://www.padil.gov.au

Catalogue of Life

Integrated Taxonomic Information System (ITIS)

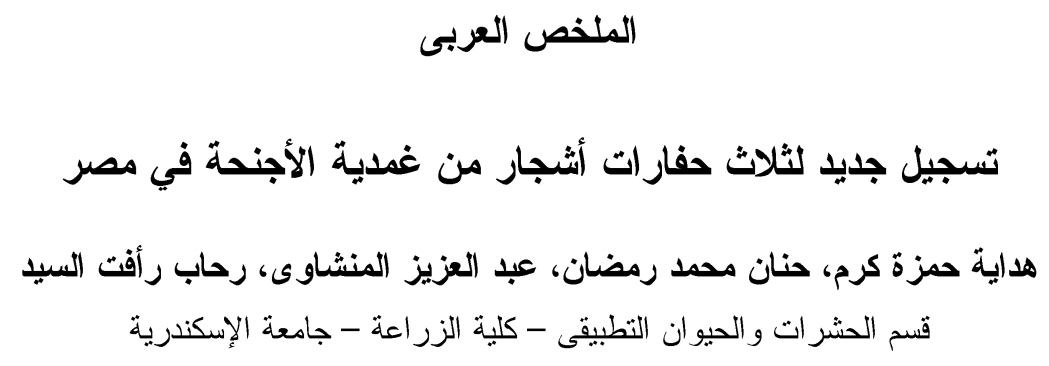

تم في هذالبحث تسجيل جديد لثلاث أنواع من حفار ات الأشجارمن رتبة غمدية الأجنحة لأول مرة في مصر

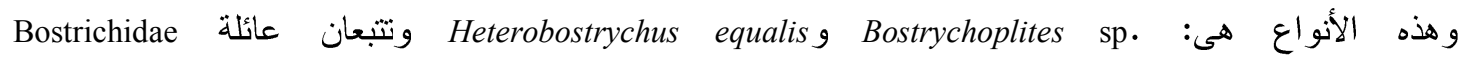
و النو ع) Acanthoscelides macrophthalmus (Schaeffer, 1907) ويتبع عائلة Bruchidae. تم وصف الأنو اع بالتفصيل مع رسمها بو اسطة المجهر وكذلك ذكر مكان وزمان جمعها و عو ائل هذه الأنو اع و نوزيعها الجغر افى. 